\title{
Chemical Growth Retardant Application to Lisianthus
}

\author{
Brian E. Whipker, Robert T. Eddy, and P. Allen Hammer \\ Department of Horticulture, 1165 Horticulture Building, Purdue University, \\ West Lafayette, IN 47907-1165
}

Additional index words. Eustoma grandiflorum, daminozide, paclobutrazol, uniconazole

Lisianthus [Eustoma grandiflorum (Shinn.)] is an annual with blooms that range from purple to white. Evaluators at the U.S. Dept. of Agriculture Florist and Nursery Crops Laboratory of Beltsville, Md., found lisianthus to be an ideal pot plant when grown as a pinched plant treated with chemical plant growth retardants (PGRs) (Roh and Lawson, 1984).

Several researchers have conducted studies with PGRs to control lisianthus height; foliar sprays of $2500 \mathrm{mg}$ butanedioic acid mono(2,2-dimethylhydrazide) (daminozide)/ liter, applied twice at a 7- and 14-day interval, and single 5000- or 7500-mg.liter ${ }^{-1}$ sprays are effective in controlling plant height (Halevy and Kofranek, 1984; Hammer and Fultz, 1985; Starman, 1991a, 1991b; Tjia and Sheehan, 1986). Ancymidol applied as a $0.5-\mathrm{mg}$ a.i./pot soil drench was effective in controlling height of a white cultivar (Halevy and Kofranek, 1984). [(E)-1-(4-chlorophenyl)-4,4-dimethyl2-(1,2,4-triazol-yl)penten-3-ol] (uniconazole) sprays of 5 and $10 \mathrm{mg} \cdot$ liter $^{-1}$ and $0.2 \mathrm{mg}$ a.i./pot as a drench also were effective (Starman, 1991a, 1991b). Varietal differences did exist in studies that tested more than one cultivar, but to our knowledge, limited information is available on the effectiveness of [ $(2 R S, 3 R S)$ 1-(4-chlorophenyl)-4,4-dimethyl-2-(1,2,4triazol-yl)penten-3-ol] (paclobutrazol) or the response of the three lisianthus color cultivars to PGRs. This study was conducted to compare the effectiveness of paclobutrazol, daminozide, and uniconazole on plant height and days to flowering for blue, pink, and white lisianthus cultivars.

Seedling plugs of lisianthus cultivars Yodel Pink, Yodel Blue, and Yodel White were planted into 0.45 -liter round pots on $14 \mathrm{Apr}$. 1993. The root medium contained 1 soil : 2 sphagnum peat $: 2$ perlite (by volume) amended with (all per cubic meter of mix) $890 \mathrm{~g}$ $\mathrm{Ca}\left(\mathrm{H}_{2} \mathrm{PO}_{4}\right)_{2}, 593 \mathrm{~g} \mathrm{KNO}_{3}, 593 \mathrm{~g} \mathrm{MgSO}_{4} \cdot 7 \mathrm{H}_{2} \mathrm{O}$, $4.75 \mathrm{~kg}$ ground limestone, and $74 \mathrm{~g}$ Peter's fritted trace elements no. 555 (Peters, Allentown, Pa.). Plants were fertilized at each watering with $\mathrm{N}$ at $201 \mathrm{mg} \cdot \mathrm{liter}^{-1}$; this was sup-

Received for publication 3 May 1994. Accepted for publication 2 July 1994. Journal paper no.14202 of the Agricultural Experiment Station of Purdue Univ., West Lafayette, Ind. Thanks to Vaughan's Seed Co. for supplying the seedlings and Uniroyal and Valent Chemical companies for grant support. The cost of publishing this paper was defrayed in part by the payment of page charges. Under postal regulations, this paper therefore must be hereby marked advertisement solely to indicate this fact. plied from $\mathrm{KNO}_{3}, \mathrm{Ca}\left(\mathrm{NO}_{3}\right)_{2}$, and $\mathrm{NH}_{4} \mathrm{NO}_{3}$, at concentrations of 71,65 , and $65 \mathrm{mg} \cdot \mathrm{liter}^{-1}$, respectively. In addition, plants received $\mathrm{K}$ at $200 \mathrm{mg} \cdot \mathrm{liter}^{-1}$ from $\mathrm{KNO}_{3}$ and $\mathrm{P}$ at $46 \mathrm{mg} \cdot \mathrm{liter}^{-1}$ supplied from $75 \%(\mathrm{w} / \mathrm{w})$ technical grade $\mathrm{H}_{3} \mathrm{PO}_{4}$ in the irrigation system. Greenhouse night/day set points were $18 / 24 \mathrm{C}$. The plants were grown under natural daylengths. Plants were pinched, leaving four to six nodes on 14 May. On 2 June, five PGR treatments (mg.liter ${ }^{-1}$ ) were applied as foliar sprays using a volume of $204 \mathrm{ml} \cdot \mathrm{m}^{-2}$ : daminozide at 2500 and 5000 , paclobutrazol at 20 , and uniconazole at 5 and 10, plus a nontreated control. A completely randomized design of six single-plant replicates was used. When the first inflorescence opened, plant height was measured from the pot rim to the top of the plant, and the number of days from transplanting until flowering was recorded. Data for all three cultivars were analyzed together using analysis of variance by general linear model procedures (SAS Institute, 1990). Significantly different means were separated by least significant differences (LSD) at $P \leq 0.05$.

The results of the PGR applications were significant at the treatment $\times$ cultivar interaction. Foliar spray applications of $5000 \mathrm{mg}$ daminozide and 5 or $10 \mathrm{mg}$ uniconazole/liter had the greatest effect on plant height of 'Yodel Blue', with a reduction of $32 \%, 40 \%$, and $36 \%$, respectively, compared to the control (Table 1). For 'Yodel Pink' and 'Yodel White', $5000 \mathrm{mgdaminozide/liter} \mathrm{reduced} \mathrm{plant} \mathrm{height}$ by $30 \%$ and $37 \%$, respectively, compared to the control. Uniconazole at 5 and 10 mg.liter ${ }^{-1}$ also reduced 'Yodel Pink' plant height by $27 \%$ and $28 \%$, respectively, compared to the control. For 'Yodel White', $10 \mathrm{mg}$ uniconazole/ liter reduced plant height by $23 \%$, compared to the control. At the concentration used, paclobutrazol had little effect on reduc- ing plant height for any of the cultivars. The effects of the PGR treatments on the number of days from transplanting to flowering were similar for all three cultivars. The use of $5000 \mathrm{mg}$ daminozide and 5 or $10 \mathrm{mg}$ uniconazole/liter significantly delayed flowering by at least 3 days [85.1, 82.9, and 83.2 days, respectively (LSD $=2.33)$ ] when compared to the control (79.8 days).

The variations in cultivar response to the PGRs we observed are probably due to differences in vigor of the three cultivars. Significant differences in overall plant height existed among the cultivars. 'Yodel White' was the most vigorous cultivar, growing to $46.8 \mathrm{~cm}$ when untreated, while 'Yodel Pink' $(39.9 \mathrm{~cm})$ and 'Yodel Blue' $(32.6 \mathrm{~cm})$ were shorter. Rates of PGRs higher than those used in this study may be more effective in producing suitable pot-sized plants for the vigorous cultivars.

The degree of height control achieved with uniconazole agrees with earlier work done with 'Yodel Blue' by Starman (1991a, 1991b), although our study resulted in plants that were $52 \%$ and $34 \%$ shorter, respectively, for 5 and $10 \mathrm{mg}$ uniconazole/liter than Starman's. The 5000-mg daminozide and 5- and 10-mg uniconazole/liter treatments were the most effective in controlling plant height and produced the most marketable-sized plants, with only a minimal delay in flowering. Paclobutrazol at $20 \mathrm{mg} \cdot \mathrm{miter}^{-1}$ had little effect on lisianthus plant height. Further research will need to be conducted to determine optimal rates for paclobutrazol as an effective PGR on lisianthus.

\section{Literature Cited}

Halevy, A.H. and A.M. Kofranek. 1984. Evaluation of lisianthus as a new flower crop. HortScience 19:845-847.

Hammer, P.A. and C. Fultz. 1985. The effect of BNine SP on height of lisianthus. Focus on Floriculture 13(4):1-3.

Roh, M.S.M. and R.H. Lawson. 1984. The lure of lisianthus. Greenhouse Manager 2(11):103-106, 112-121.

SAS Institute. 1990. SAS/STAT user's guide, vol. 2, version 6, 4th ed. SAS Inst., Cary, N.C.

Starman, T.W. 1991a. Lisianthus growth and flowering responses to uniconazole. HortScience 26:150-152.

Starman, T.W. 1991b. Corrigendum. HortScience 26:333.

Tjia, B. and T.J. Sheehan. 1986. Chemical height control of Lisianthus russellianus. HortScience 21:147-148

Table 1. Plant growth retardant (PGR) effect on height of lisianthus cultivars Yodel Blue, Yodel Pink, and Yodel White.

\begin{tabular}{|c|c|c|c|c|}
\hline \multirow[b]{2}{*}{ PGR } & \multirow[b]{2}{*}{$\begin{array}{c}\text { Concn } \\
\left(\mathrm{mg} \text { liter }^{-1}\right)\end{array}$} & \multicolumn{3}{|c|}{ Cultivar } \\
\hline & & $\begin{array}{c}\text { Yodel } \\
\text { Blue } \\
\text { ht }(\mathrm{cm})\end{array}$ & $\begin{array}{c}\text { Yodel } \\
\text { Pink } \\
\text { ht }(\mathrm{cm})\end{array}$ & $\begin{array}{c}\text { Yodel } \\
\text { White } \\
\text { ht }(\mathrm{cm})\end{array}$ \\
\hline None & --- & 32.6 & 39.9 & 46.8 \\
\hline \multirow[t]{2}{*}{ Daminozide } & 2500 & 31.9 & 34.1 & 38.1 \\
\hline & 5000 & 22.2 & 27.8 & 29.6 \\
\hline Paclobutrazol & 20 & 29.8 & 40.1 & 42.1 \\
\hline \multirow[t]{2}{*}{ Uniconazole } & 5 & 19.7 & 29.2 & 45.1 \\
\hline & 10 & 20.9 & 28.7 & 35.8 \\
\hline Significance & & & $* *$ & \\
\hline $\operatorname{LSD}(\alpha=0.05)$ & & & 6.24 & \\
\hline
\end{tabular}

* Significant at $P \leq 0.01$ for the treatment $\times$ cultivar interaction. 